\title{
Paraplegia Following Spinal Anaesthesia
}

\author{
R De S Kulasiri ${ }^{1}$ *T G Dissanayakege ${ }^{2}$ \\ Consultant Anaesthetist ${ }^{1}$, National Hospital of Sri Lanka. Medical Officer \\ Anaesthesiology and Critical Care ${ }^{2}$, Base Hospital Kanthalai, Sri Lanka.
}

*Corresponding author: thisaragd@gmail.com

\begin{abstract}
Paraplegia, a serious complication following spinal anaesthesia is associated with significant morbidity and even mortality. Though extremely rare, spinal anaesthesia has been shown to facilitate the manifestation of paraplegia secondary to spinal cord compression due to undiagnosed vertebral metastases. Similar presentation in a patient with a history of renal cell carcinoma is reported here where the patient had no neurological impairment preoperatively. Attention to preoperative neurological assessment in susceptible cases of spinal metastases is very important.
\end{abstract}

Keywords: paraplegia; spinal anaesthesia; spinal metastases; spinal haematoma; renal cell carcinoma; neurological examination

\section{Case report}

A 55 year old male presented with painful bleeding per rectum of three months duration. $\mathrm{He}$ was diagnosed to have multiple chronic anal fissures and scheduled for lateral sphincterotomy under spinal anaesthesia. He did not reveal previous comorbid conditions involving major organ systems other than renal cell carcinoma, for which he had undergone left sided nephrectomy eight months ago. Metastatic disease had been excluded at that time. However, he had defaulted subsequent clinic follow-up. He had no significant back ache or neurological impairment during the anaesthetic preop assessment. Hence, a thorough neurological examination was not performed preoperatively. Baseline haematological and biochemical investigations were normal. Plain radiography had not been done.

Saddle block was performed under strict aseptic conditions. Sub arachnoid space was located by a $25 \mathrm{G}$ pencil point spinal needle introduced at L4/L5 interspace in a single attempt. $1.3 \mathrm{ml}$ of $0.5 \%$ hyperbaric bupivacaine with $0.3 \mathrm{ml}$ of fentanyl was injected and a sensory block up to L1 spinal segment was achieved. Intra operative course was uneventful, where all the vital parameters were maintained within normal range. The effect of spinal anaesethetic agents had worn off 3 hours later. After an uncomplicated postoperative course, the patient had been discharged the following day.

From post op day 5, patient had experienced a low back ache of increasing severity. Thereafter he had developed a progressive asymmetrical bilateral lower limb weakness and has got readmitted on postop day 6. There was no history of fever, headache or fall preceding above events.

Following readmission, he was in pain (pain score 3) and was afebrile. Neurological examination revealed spinal tenderness at lower thoracic and lumbar regions with asymmetrical bilateral lower limb weakness. The positive neurological findings were; impaired muscle power of both knee joints (extension/flexion-Left KJ 4/4, Right KJ 4/5) and absent $\mathrm{B} / \mathrm{L}$ knee jerk. His bladder and bowel 
function was not affected. There was no sensory level. Other major organ systems were clinically normal.

FBC, ESR, renal function tests, liver profile, USS abdomen, X-ray thoracolumbar spine and CXR was done to investigate the problem. Urgent MRI scan of thoracolumbar spine was arranged so as to exclude spinal cord haematoma as early as possible.

$\mathrm{X}$ ray thoracolumbar spine (Figure 1) showed left sided T12 vertebral pedicle destruction. MRI scan of thoracolumbar spine (Figure 2), which was performed within 12 hours after the admission, confirmed metastatic deposits on T12 vertebral body extending to left pedicle causing encroachment of spinal canal and cord compression. Other haematological and biochemical investigations were normal.

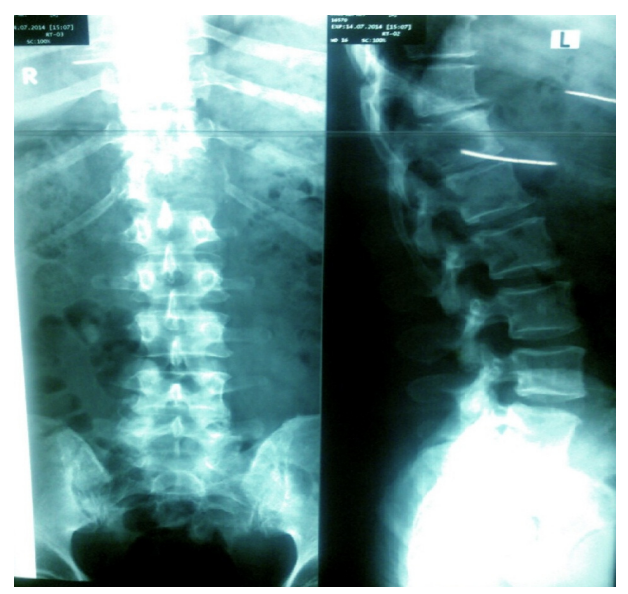

Figure 1: X-ray thoracolumbar spine (AP/Lateral), showing T12 vertebral pedicle destruction

The patient was given a course of i.v. dexamethasone to relieve spinal cord oedema. Multimodal analgesics were given for pain. His neurological deficit did not improve. Palliative care was indicated since the patient was not an ideal candidate for surgical metastasectomy as decided by the neurosurgical team. Oncology referral was done and the patient was transferred to Cancer Institute Maharagama for radiotherapy.

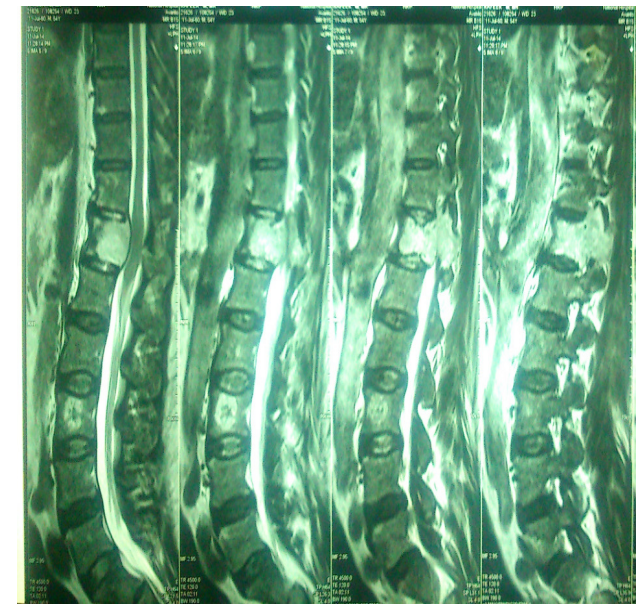

Figure 2: T2 weighted MRI scan thoracolumbar spine showing metastatic deposits on T12 vertebral body causing encroachment of spinal canal

\section{Discussion}

Our main concern was to initially rule out any rapidly progressive lesion affecting the spinal cord, which may or may not have a correlation with the preceding anaesthetic procedure.

Neurological complications and it's sequelae following regional anaesthesia can be classified into three classes. ${ }^{1}$ Those,

1. produced by non anaesthetic causes.

2. related to underlying pathology in which regional anaesthesia can be a contributing factor.

3. related to the regional anaesthesia.

Accordingly, we needed to exclude a possible spinal cord haematoma, spinal cord abscess, undiagnosed vertebral metastases from the primary renal cell carcinoma or undiagnosed vertebral tuberculosis, which were our main differential diagnoses. Other less common causes including the cauda equina syndrome, arachnoiditis, transverse myelitis, anterior spinal artery syndrome and acute vertebral disc disease were excluded clinically.

Spinal cord haematoma classically manifests as acute onset severe, often radiating back pain followed by signs and symptoms of nerve root and lower spinal cord compression which develops minutes to days later. Factors which increase the 
risk of spinal haematoma formation are; female gender, older age, traumatic needle insertions and concomitant use of anticoagulants or antiplatelets $^{2}$ which were not identified in our patient. Urgent spinal MRI (ideally within 12 hours) $)^{3}$ is crucial for early recognition and accurate diagnosis. Prompt decompression with evacuation of haematoma may result in significant improvement even in severe cases. We managed to get a MRI scan done within 12 hours after admission which excluded the presence of spinal cord haematoma.

Spinal abscess was unlikely in this patient as he did not have risk factors such as immunodeficiency or diabetes and symptoms such as fever, nuchal rigidity, headache or local symptoms such as erythema, rash with rising white blood cell count and ESR. ${ }^{4}$

A close association between spinal anaesthesia and manifestation of paraplegia from cord

\begin{tabular}{|c|c|c|c|c|c|c|c|}
\hline Year & Authors & $\begin{array}{l}\text { Anaesth } \\
\text { esia }\end{array}$ & $\begin{array}{l}\text { Tumour } \\
\text { origin }\end{array}$ & $\begin{array}{l}\text { Onset } \\
\text { time }\end{array}$ & $\begin{array}{l}\text { Level of } \\
\text { tumour }\end{array}$ & $\begin{array}{l}\text { Local } \\
\text { anaesthetic } \\
\text { \& dose }\end{array}$ & $\begin{array}{l}\text { Diagnosti } \\
\text { c tool }\end{array}$ \\
\hline 1946 & $\begin{array}{l}\text { Nicholson } \\
\text { and Everson }\end{array}$ & $\begin{array}{l}\text { Continu } \\
\text { ous } \\
\text { spinal }\end{array}$ & Stomach & 24 hour & $\begin{array}{l}\text { Not } \\
\text { stated }\end{array}$ & Tetracaine & Not stated \\
\hline 1976 & Densoyers et al & Spinal & Prostate & $2^{\text {nd }}$ day & T4 & $\begin{array}{l}\text { Hyperbaric } \\
\text { tetracaine } 14 \\
\mathrm{mg}\end{array}$ & Myelogram \\
\hline 1991 & Mutoh et al & Spinal & Prostate & $2^{\text {nd }}$ day & $\begin{array}{l}\text { T10 to } \\
\text { T11 }\end{array}$ & Not stated & $\begin{array}{l}\text { Myelogram } \\
\text {. СT }\end{array}$ \\
\hline 1992 & Bessac et al & Spinal & Prostate & $2^{\text {nd d }}$ day & $\begin{array}{l}\text { Not } \\
\text { stated }\end{array}$ & Not stated & MRI \\
\hline 1992 & Graham et al & Spinal & Prostate & $2^{\text {nd }}$ day & $\mathrm{T} 12$ & $\begin{array}{l}\text { Hyperbaric } \\
\text { bupivacaine }\end{array}$ & Myelogram \\
\hline 2002 & Karamaz et al & $\begin{array}{l}\text { Combin } \\
\text { ed }\end{array}$ & $\begin{array}{l}\text { Endometri } \\
\text { al }\end{array}$ & $10^{\text {th }}$ day & T6 & $\begin{array}{l}\text { Hyperbaric } \\
\text { bupivacaine }\end{array}$ & CT/MRI \\
\hline 2008 & Cherng et al & Spinal & $\begin{array}{l}\text { Not } \\
\text { identified }\end{array}$ & 8 hour & $\begin{array}{l}\text { T9 to } \\
\text { T11 }\end{array}$ & $\begin{array}{l}\text { Hyperbaric } \\
\text { bupivacaine }\end{array}$ & MRI \\
\hline $\begin{array}{l}\text { Onset } \\
\text { compu }\end{array}$ & $\begin{array}{l}\text { time to new ne } \\
\text { mography, MRI- }\end{array}$ & tic resona & $\begin{array}{l}\text { after surg } \\
\text { imaging }\end{array}$ & Combined- & mbined spin & and epidural a & sthesia, CT- \\
\hline
\end{tabular}
compression due to undiagnosed vertebral metastases has been reported in literature. ${ }^{5}$

(Table 1)

Spinal tumours can cause acute neurological deterioration following lumbar puncture in many ways. Traction on the spinal cord induced by cerebrospinal fluid pressure difference is one called "spinal coning". ${ }^{6}$ Another theory suggests that the injected local anaesthetic cannot be properly diluted if the CSF flow is obstructed by a space occupying lesion at a higher level of the spinal cord so that neurotoxicity may ensue due to high concentration of local anaesthetic. ${ }^{7}$

Bone metastases from renal cell carcinoma (RCC) occur in up to $50 \%$ of patients, half of which is located in the spine. The most frequent site is the vertebral body because of its abundant vascularization and the presence of bone marrow inside. Metastases have also been reported among those with RCC, who had undergone

Table 1: Survey reports of paraplegia after regional anaesthesia in patients with a metastatic spinal tumour

nephrectomy and have been considered as "no evidence of metastases" over the preceding years. Delay in diagnosis is likely in the presence of back pain only. Hence, it is recommended that the probability of vertebral metastases must be considered in every patient with past history of RCC. $^{8}$

Plain radiography is of poor sensitivity as $50 \%$ of bone must be eroded before there is a noticeable change. ${ }^{9}$ Currently, MRI remains the gold standard imaging technique for assessing spinal metastases and is more sensitive than CT or bone scan. ${ }^{8}$

Early diagnosis of metastatic spinal disease is important because functional outcome depends on neurologic condition at the time of presentation. 
However there is no evidence that early diagnosis improves survival. ${ }^{8}$

Management of spinal metastases involves multidisciplinary care. Sunitinib is the first line pharmacological therapy. Metastasectomy should be performed in patients with metastatic disease where disease is resectable and patient has good cardiovascular reserve. RCC is known to be radiotherapy and chemotherapy resistant and immunotherapy is associated with significant toxicities. However, radiotherapy to bone metastases from RCC induces significant relief of pain. $^{10}$

\section{Conclusion}

Though extremely rare, paraplegia following spinal anaesthesia in patients with previously undiagnosed metastatic spinal tumours has been reported. Therefore, anaesthetists should be vigilant to detect susceptible cases of spinal metastases before SAB. The importance of detailed preop neurological assessment in suspected cases cannot be overlooked.

\section{References}

1. Bromage $\mathrm{P} R$, Neurological complications of subarachnoid and epidural anaesthesia. Acta Anaesthesiol Scand 1997; 41: 439-444. http://dx.doi.org/10.1111/j.1399-6576.1997.tb04 $\underline{721 . x}$

2. Horlocker T T, Wedel D J, Benzon H, et al. Regional anesthesia in the anticoagulated patient: defining the risks (the second ASRA Consensus Conference on Neuraxial Anesthesia and Anticoagulation). Regional Anesthesia and Pain Medicine. 2003; 28: 172-197.

PMid: 12772135

3. Liao C C, Lee S T, Hus W C, et al. Experience in the surgical management of spontaneous spinal hematoma. Journal of neurosurgery. 2004;100:38-45.

PMid:14748572

4. Brooks H, May A. Neurological complications following regional anaesthesia in obstetrics.
British Journal of Anaesthesia. 2003; 3(4): 111-14.

5. Cherng Y G, Chen I Y, Liu F L, Wang M H. Paraplegia following spinal anaesthesia in a patient with an undiagnosed metastatic spinal tumour. Acta Anaesthesiol Taiwan 2008;46(2):86-90. http://dx.doi.org/10.1016/S1875-4597(08)60033$\underline{8}$

6. Mutoh S, Aikou I, Ueda S. Spinal coning after lumbar puncture in prostate cancer with asymptomatic vertebral metastasis: a case report. Journal of urology. 1991;145;834-5.

PMid:2005711

7. Nicholson M J, Eversonn U H. Neurologic complications of spinal anaesthesia. Journal of American Medical Association. 1946;132:679-85 http://dx.doi.org/10.1001/jama.1946.0287047000 $\underline{5002}$

8. Gasbarrini A, Simoes C E, Cappuccio M, Boriani S. Management of Renal Cell Carcinoma Metastasis of the spine. Emerging Research and Treatments in Renal Cell Carcinoma. First edition, In Tech : 2012;311-32

9. Gabriel K, Schiff D. Metastatic spinal cord compression by solid tumours. Seminars in Neurology 2004; 24(4): 375-83

http://dx.doi.org/10.1055/s-2004-861532 PMid:15637649

10. Ljungberg B, Bensalah K, Bex A, et al. European Association of Urology, 2013, Guidelines on Renal Cell Carcinoma: 38-49. 